\title{
Life After Death in Whitehead's Metaphysics
}

CHRISTOPHER BRONIAK

Loyola University of Chicago

\section{INTRODUCTION}

What life lies beyond the death of a human person according to the metaphysics of Alfred North Whitehead? How does objective immortality, the "stubborn fact" in the universe, the resulting satisfaction of an actual occasion, relate to the possibility of personal immortality? If personal immortality is possible, what are its characteristics?

In Whitehead's metaphysics, a viable possibility of personal immortality exists within the context of two notions: the valuation enacted by an actual occasion, and the way valuation of a temporal occasion has ongoing importance for God in God's nontemporality. Can what perishes in the concrescence, the subjective immediacy of the occasion, be saved from total elimination from the process universe? If so, a synthesis whereby both the subjective immediacy and the objective immortality of an occasion persists in God's prehension of the temporal world is possible in the intersection of God's non-temporality and the temporality of the world.

\section{IMMORTALITY AND THE HUMAN PERSON}

Before making the attempt to discover the possibility of immortality, one must ask: "Need immortality be possible; must occasions perish?" Entities "perish" (exhaust their subjective immediacy) and "become" (attain satisfaction and objective immortality) so that superseding entities can "use" the objectification of the previous entity for its own concrescence. Anything short of objectification (though it is hard to say what something might be "short of" objectification) cannot be appropriated by later occasions. "Until Ian actual occasion] attains a determinate outcome, therefore, it cannot be objectified by other entities as an actual thing." " "Becoming" in the universe needs things which have already "become."

Entities becoming and perishing does not mitigate the possibility of immortality of the human person for Whitehead. Passages from Process and Reality leave the possibility an open question. 
[A]11 actual things are alike objects... [but alsol all actual things are subjects, each prehending the universe from which it arises... . Self-identity requires that every entity have one conjoined, self-consistent function, whatever be the complexity of that function. ${ }^{2}$

Whitehead emphasizes the importance of refraining from a traditional subject/object distinction in reality. Does this also affect objective immortality? He intends objective immortality to stand in a categorical way. Yet even though the main thrust of Whitehead's metaphysics shows how subjective perishing makes objective immortality possible, something else about it suggests the possibility of another kind of immortality.

The suggestion lies in Whitehead's discussion of two kinds of fluency in the world. His metaphysics views "concrescence" as "the fluency inherent in the constitution of the particular existent," and "transition" as

the fluency. . . on the completion of the particular existent [which] constitutes that existent as an original element in the constitutions of other particular existents elicited by repetitions of process. . . . Concresence moves towards its final cause, which is its subjective aim; transition is the vehicle of the efficient cause, which is the immortal past.'

For Whitehead, time considerations primarily make genetic sense. The order of past, present and future, the familiar linear tradition of time, is inadequate. Instead, whatever is past is objective in kind, and whatever is present is subjective in kind. This perspective (and the previous quotation) makes it difficult to say how Whitehead considered an immortal present.

Whitehead's metaphysical assertions seem less forceful and more removed when moving from the microscopic level of occasions and their prehensions to macroscopic considerations of nexus and societies. They are not any less forceful, but it is a long road from occasions to anything like a human person. How is unification possible (nexus is inseparable from group of occasions), and what is the degree of this unification? Whitehead writes that a multiple nexus is "how those actual entities are really together. . . by reason of the objective immortality of their real mutual prehension of each other."

The objective immortality gained by an actual entity in its satisfaction is not opposed to or contradictory of the possibility of personal immortality. It is not a contrast of objective immortality, but a synthesis of objective immortality and subjective immedia- 
cy. Objective immortality is a way the concreteness of the valuation of an entity is established. Therefore, the investigation into the possibility of personal immortality ought not guard against "objectification," but against abstractions occuring in hypothetical divisions of concrescence and against the eliminations and losses resulting from abstractions. ${ }^{3}$

How are both past and present entities grouped into a single unity? What notion of "future" is involved? Do particular occasions "give up" their subjective immediacy so new subjective immediacies of actual occasions can arise? Or do they "use up" their subjective immediacy in their own concrescence?

Whitehead makes these problems more explicable in Modes of Thought. The usual mind-body problem is avoided through Whitehead's understanding of nexus and societies. Also, the problem of how both past and present intermix with each other is intuitively plausible in Whitehead's explanation of the human person as a single substance.

[0]ur bodies lie beyond our own individual existence. And yet they are a part of it. We think of ourselves as intimately entwined in bodily life that a man is a complex unity--body and mind. But the body is part of the external world, and continuous with it."

What is "already finished" is our body, the immediately antecedent states of the body. We depend upon these states being finished in order to live. But to conceive of the body purely in instrumental terms is contrary to whitehead. It is continuous with the external world, where unities of any degree of complexity are found. To separate the mind and body into categories is wroncheaded, expecially in Whitehead's scheme, for there is no way to teli where one ends and the other begins. "lolur feeling of bodily-unity is a primary experience. . . . No one ever says, Here am I, and I have brought my body with me."I

For Whitehead, the human person is constituted by a multiplicity of occasions characterized by the parallel idea of the subjective aim of an occasion. The multiplicity of these occasions have running through them a strand of self-identity which Whitehead calis "personal unity." The personal unity of the complex society called human person parallels at the macroscopic level the function entailed by the subjective aim of an occasion at the microscopic level. He cites Plato's doctrine of the Receptacle in the Timaeus to support the concept of personal unity "whose sole function is the imposition of a unity upon the events of nature." This thread is important in that "I those events] obtain their actuality by reason of emplacement within [a single locus] community.". 
The subjective aim of an occasion begins with its "initial aim." John Cobb, in A Christian Natural Theology, understands Whitehead' $\frac{\mathrm{s}}{\mathrm{s}} \mathrm{\text {useoftheinitial }}$ aim as having at least three sources of meaning. The first is aim as defined by the eternal objects; the second is aim as "a focus upon the satisfaction aimed at;" and third is the act of "aiming at," the immediate feeling of an occasion of its subjective aim." Cobb's chosen purpose emphasizes the third source of meaning, "upon the act of aiming itself." This is the emphasis or aim important for the possibility of personal immortality.

\section{ISSUES ABOUT TIME AND GOD'S CONSEQUENT NATURE}

Time-as-present and time-as-past are well-grounded in Whitehead's considerations of nexus and societies. What is his conception of time beyond the present, time-as-future? This dimension is "not so evident in terms of the doctrine of the subject-object structure of experience." Instead, time-as-future finds a place in the present in a formally parallel way as time-aspast finds its place. "Immediate existence requires the insertion of the future in the crannies of the present." 10

Immortality must be for all times, past, present and future. If any "vehicle" is going to lend itself to the possibility of subjective immortality of actual occasions, it must be within God's consequent nature. In The Lure of God, Lewis S. Ford writes "there has been a tendency to consider each nature [in God's primordial and consequent natures] as having its own distinctive functions, each operating with some degree of independence from the other." 1 " But Ford insists this tendency is inaccurate and inappropriate. These two natures are inextricably intertwined, with the primordial nature, as the source of possible ideals, serving as initial aims for occasions, and the consequent nature experiencing the actual world which "forms the basis whereby God can specify which aims are relevant for which occasions." 12

Cobb gives an even greater emphasis upon the way God's consequent nature experiences the actual world. That experience is not merely the "taking account" of an occasion's "public behavior;" instead, what God takes up "is our experience in the full intimacy of [that experience's] subjective immediacy."'s Cobb's comment indicates how subjective immediacy is experienced by God even as the occasion is in its process of concrescence. The important point is not to avoid objectification qua objectification but to avoid objectification qua an "incomplete" or "less than fully realized" objectification. "i"

The question of whether something like "survival" is possible for subjective immediacy is caught between 
the temporal category of the future and the way God's experience of the temporal world derives from God's nontemporality. So beginning prior to the perishing of the occasion,

God's presence is internal to himself, derived from his nontemporality, but out of that and the past which he recieves from the world he creates a new future, as he transforms his pure possibilities into real possibilities, that is, realizable possibilities under the conditions of the world. . . [God] is a nontemporal actuality who influences us by the future he now creates: by means of the real possibilities he persuades the world to actualize. is

The creativity in God differs from the creativity in other actual entities (while maintaining there is only "creativity"). In the consequent nature, God performs the role of working with metaphysical rules and constructs in "creating" some particular cosmos. This is the transformation from pure possibilities (metaphysics) to real possibilities (cosmology). Other actual entities "create" within the cosmos God has delivered; they narrow the cosmos a bit more. Hence a second transformation from real possibilities (cosmology) to real actualities (ontology).

Why do considerations of creativity become crucial for the possibility of subjective immortality? To be present, to be a subject, is to experience, and "each moment of experience confesses itself to be a transition between two worlds, the immediate past and the immediate future." is Reflection upon the future leads to the desire to understand what might be the "form" (naive Aristotelean sense) of the future immanent in the present. Whitehead has already stated that the "form" of the past gains an immanent foothold in the present by way of the objective immortality of actual occasions whose subjective immediacy have "perished" and have achieved a metaphysical status of "stubborn fact" for subsequent concrescing occasions. But "the future must be present in some different sense to the objective immortality of the individual occasions of the past."1' The way the doctrine of the future ought to be understood is "in terms of the account of the process of self-completion of each individual actual occasion."

The actual occasion's role in this process universe is to be, to complete itself. But how does God "complete" himself? An occasion issues in satisfaction; but what is the sense of satisfaction for God? Ford and Marjorie Suchocki suggest that "if for the occasion concrescence issues in satisfaction, then for God satisfaction must issue in concrescence." They begin from this premise: "God's nontemporal satisfac- 
tion, insofar as it is relevant, precedes the everlasting concrescence it issues into." objectivity exhibit satisfaction; God, in satisfaction, exhibits objectivity (a clumsy way of saying "being"). The relation of concrescence and satisfaction in God is a peculiar issue for Whiteheadean metaphysics.20 The subjective immediacy of personal immortality finds itself in the intersection of the temporality of occasions and God's nontemporality, "the everlasting." This raises the question of whose immediacy is now involved in the prehension of the temporal world: is it God's subjectivity "at work," or is it the subjectivity of the concresced occasion? Ford and Suchocki respond to this by saying the experience "is God's materially, . . mine having perished. But it is mine formally, for I am the author of that particular way of experiencing that situation."21

\section{GOD REENACTS THE SUBJECTIVE AIM OE A "PERISHED" OCCASION}

A section from Process and Reality lends support to the idea of subjective immortality.

There are. . . four creative phases in which the universe accomplishes its actuality. . . [The third] is the phase of perfected actuality, in which the many are one everlastingly, without a qualification of any loss either of individual identity or of completeness of unity. In everlastingness, immediacy is reconciled with objective immortality. This phase derives the conditions of its being from the two antecedent phases Inamely, from the nontemporal conceptual origination phase and the temporal physical origination phase].22

How the past and the present are said to be one reaches a resolution in this creative third phase. The phase employs "everlastingness," a temporal concept providing contextual reference for the categories of temporality and nontemporality. Actual occasions are temporal, but it is imprecise to speak of God as simply nontemporal. To limit God in this way damages God's immanence in the World. Whitehead more appropriately speaks of "the everlasting nature of God, which in a sense is nontemporal and in another sense is temporal"; this nature of God "may establish with the soul a peculiarly intense relationship of mutual immanence." 23

This third phase, where immediacy is reconciled with objective immortality, supports a synthesis of these two ideas and not the displacement of one by the other. The perishing of actual occasions in the temporal world makes for their objective immortality in God; but for the aim of the occasion to be intense and 
complete enough to fit God's experiencing of the World, the requisite immediacy must be appropriate to the intensity and completeness. So the immediacy must be attributable both to God and to the occasion. Objective immortality does not make subjective immediacy logically impossible, but is a necessary correlate of personal immortality.

This creative phase in no way eliminates the difference between God and other actual entities. The creativity at work in both God and the other entities is the same creativity, but in different manifestations. The creativity of finite occasions is relative to finite occasions, allowing it to transcend its past but not its future. But the creativity at work in God is absolute, transcending every actuality by taking those actualities and incorporating them into God's being. ${ }^{24}$

If everlastingness provides a context whereby temporal occasions move from temporality, yet preserve their own "presence," then the occasion's subjective immediacy persists (is not eliminated) "in spite of." the occasion's objective immortality. It is misleading, however, to identify the persisting immediacy as the subjective immediacy of the occassion, for that immediacy has its "being" in the "becoming" of the occasion. Once an occasion is, Whitehead insists, subjective immediacy ceases to be. Still, the sufficient intensity of feeling in God's prehension of the World is needed, so something like immediacy must be at work. Whose immediacy it is has not been determined, but it need not be God's immediacy (cf. Ford and Suchocki, $n$. 21 above).

Cobb thinks a problem exists if this is to be "10cated" in God's consequent nature, possibly conflicting with the principle "contemporaries do not prehend each other." This can be avoided, Cobb thinks, by considering that "God also prehends temporal occasions in their contemporaneity, and therefore shares the immediacy of every becoming occasion." 2 s

Ford and Suchocki conceive of the being of an immortal subjective immediacy as one of contemplation.

[I In God we no longer act but contemplate. . . . Occasions in their coming-to-be struggled with incompatibilities, but as reenacted in being they no longer find that competitiveness need be the case. . . There is no more competitive vying for one value at the expense of another, for now all chosen values are now quite actual.20

As temporalities, occasions in God exhaust their futures and begin to "knit together" in God. The first part of the "knitting" occurs at the level of the particular personal life to which those occasions belonged, and the second part erases the distinction of 
particular personalities such that they merge along the lines of characteristics like personal affinity and affection. 27

\section{HOW SUBJECTIVE IMMEDIACY PERSISTS: VALUATION}

Creativity is the energy of a process universe. Finite actualities of experience exhaust their creativity in a single momentary act, an act of self-unification superseded by other acts." God draws all these entities into an inexhaustible unity. "since the inner aim informing divine creativity and impelling it forward is infinite, seeking the realization of every possibility, each in its own season." 2

Whitehead discusses whether the "complete selfidentity" of occasions must mitigate the possibility of subjective immediacy or exhaust an occasion's subjective aim as it is reenacted in God. Completeness depends on whether an occasion in 1 ts becoming persists in the same way as beyond its becoming. "[C]omplete self-identity can never be preserved in any advance to novelty." There is some sense in saying $I$ am the same person I was when I was five years old, and yet thers is at least as much sense (if not more) in saying that who I was at five years old vastly differs from who I am today. What this does, says Whitehead, neither proves nor disproves the possibility of personal immortality.30

In his article "The Disembodied Soul," John Bennett considers whether anything like personal immortality is possible outside of a subjectivity's physical environment, namely, its body. He is against this possibility. for the environment of an occasion affects the complexity of the occasion, in turn affecting personal identity. "Thus apart from the body, the soul would - . not have the variety of content and degree of novelty that properly characterize a living person. "I

Bennett rightly notices the environment as important to the subjective immediacy of a concrescing occasion, but wrongly estimates the immediacy's capacity to function only within a "body" environment. Whitehead and Ford argue for another element, though not strictly an "environment" of nexus or societies, but still intense enough to account for the complexity of personal identity. They refer to this element as valuation.

If his metaphysics is simply a matter of dogmatic application of principles to phenomena, Whitehead recognizes, it becomes difficult to explain something like the persistence of personal identity even in the dayto-day living of ordinary people. Instead, "the survival of personal identity within the immediacy of a present occasion... is a partial negation of its transitory character." What does Whitehead point to in this survival? "It is the introduction of stability by the influence of value." 
Moreover, "the effective realization of value in the world of change should find its counterpart in the world of value. This means temporal personality in one world involves immortal personality in the other."3" These are considerations Ford and Suchocki bring up about the possibility of God's ongoing satisfaction ( $n$. 19 above). Temporal occasions in their concrescence realize value in the changing, temporal world. But what about the "world of value," the unchanging world, the nontemporal world of God?

If one expands upon Whitehead's quotation, perhaps something like "the effective realization of change" meets God's ongoing satisfaction. It is an ongoing satisfaction, for nothing finishes or exhausts God. But the value attained by the occasion "completing" God is a real sense of satisfaction, especially as considered from the viewpoint of God's consequent nature.

But the only way a particular value of an occasion completes God is if with the value goes an intensity that is nothing less than the subjective immediacy the occasion enjoys prior to its objective immortality. What is crucial is completeness and concreteness, as opposed to abstractions and the losses resulting from those abstractions." The value of a chair is valued as a chair because the occasions that gave themselves over to objectivity gave themselves over as a chair and not as a piece of wood or of metal. Perhaps it also holds that the value each of us gives ourself over to is valued by God for its particular value.

Ford gives some hints for reconciling valuation with the earlier problem raised by Bennett concerning a disembodied soul. The biblical exegesis of The Lure of
God considers how st. Paul understood the term "physical body."

"[P]hysical body," (RSV), is not soma phusikon but soma psuchikon, a "psychical body." The ordinary human body is not composed of some psychical material, but a psychical body animated by a soul or mind or psyche which organizes and directs its activity. 3

What Cartesians commonly understand as consciousness inhabiting a corporeal body is not Paul's meaning. The mind itself is "inhabited," directed and organized by "something else."

In order to meet the possibility of subjective immortality in Whitehead's metaphysics, it appears this "something else" must be the synthesis of both the subjective immediacy and the objective immortality of an actual occasion. Given Ford's observation, the perishing of the corporeal body of a person becomes immaterial. The proper environment of presently existent personal identity is not so much the corporeal as it is the psychical; however the environment is indetermi- 
nate, for the subjective immediacy beyond the death of the corporeal body is not a parallel of the corpus but of the psyche. Although Bennett asks the right question concerning the importance of environment, the environment itself varies and makes a difference to the question of disembodied immortality.

But Ford too is ready to discount disembodied survival as questionable at best, for "the soul might still be able to exist, but in such an impoverished state that it hardly seems worthwhile." he allows for the possibility of immortality by suggesting that the survival of subjective immediacy can come about "if the ongoing life of God were to provide the support for these continuing occasions of the soul which it had been accustomed to receive from the body." 6

A final consideration of this life after death is the extent to which an individual's personality persists beyond death ( $\mathrm{nn}, 22$ and 27 above). If the reconciliation of subjective immediacy with objective immortality is impossible, then Ford completely dismisses all possibility of subjective immortality."7 The self loses itself in being merged with God rather than contributing a restriction to the process universe. "Perhaps in this transfer of concern from our own life to God's we may discover this final peace."

\section{TIME, VALUATION AND IMMORTALITY}

Any possibility of the immortality of the human person in Whitehead's metaphysics cannot be conceived as the same kind of "immortality of the soul" of Plato or of Christianity. This is so on two counts. Eirst, Bennett's objection concerning the importance of the body-environment ( $n$. 31) addresses this claim. Second, it is supported by Eord's observation that what we are might not be a soul inhabiting a body, but a "something" organizing both the soul and the body for itself (n. 35), namely, the synthesis of the subjective immediacy and the objective immortality of an occasion as its subjective aim is reenacted in God. Whitehead treats "soul" as a misconception of the human person; his metaphysics does not argue for the immortality of misconceptions. Yet a person's immortality is possible in Whitehead's scheme.

The next consideration is whether valuation is more like "subjectification" or more like "objectification." Ford and Suchocki suggest (n. 21 above) that valuation is something to be met exclusively (at least from the point of view of the contributing occasion) by the occasion's subjective immediacy as it contributes to God's reenactment of its subjective aim. On the other hand, Whitehead's metaphysics lends support to valuation as a synthesis of immediacy (subjectification aspect) and immortality (objectification aspect).'" 
The suggestion of God's reenactinent of a subjective aim is, at least conceptually speaking, somewhat better accomodated as an "object" reenacted, rather than as a "subject." But whether God's reenactment is objective in the universe, not by way of God's natures but by way of God's timelessness, is uncertain. Does anything like "subject" or "object" (which Whitehead uses in a descriptive manner) still adequately describe God's reenactment in eternality? Disjunctively proposed questions of valuation ought to be rigorously avoided. Valuation must be reconsidered not as an either/or proposition of subject versus object, but as a synthesis of both subject and object, of both immediacy and immortality. Any attempts to present personal immortality in Whitehead's scheme of things must thoroughly consider the ideas of time and value. Coherently argued considerations would make it plausible for immortality to be as real and actual a situation as are occasions, nexus, societies, God, eternal objects, prehensions, and other Whiteheadean "creatures."

In a comprehensive way, Whitehead has already dealt with the way objective immortality "feeds" subjective immediacy. But to suggest that subjective immortality feeds anything like objective immediacy is off the mark. "Objective immediacy" is not a paradox, but a contradiction, for the time of objectivity (the past) cannot be reconciled with the time of immediacy (the present). But subjective immortality makes more sense if conceived as feeding God's consequent nature, and subjective immortality need not be a contradiction. It is a paradox, for the time of subjectivity (the present) submits to "immortal" time, that which is "then," "now" and "to be" always.

For Whitehead, concepts of persistence over time give rise to a world of value. "Value is in its nature timeless and immortal. Its essence is not rooted in any passing circumstance." The immediacy of a given occasion is momentary as it is viewed for the world of fact, for objectivity. But in valuation, in its being valuable, it becomes an eternal moment. "The immediacy of some mortal circumstance is only valuable because it shares in the immortality of some value." 40

Also recall Ford's remark of the damage done in considering Whitehead as too categorical regarding God's primordial and consequent natures ( $n .11$ above). Subjective immortality stands as the area of transmutation for subjective immediacies to satisfy God. They do not exhaust but fulfill God in the sense of making another happy.

Perhaps this differs from the usual considerations of being happy. Happiness is not and cannot be the end-all of God, for God is "constantly" happy. But we are caught between being "constantly" happy and being happy once and for all. In valuation, the task of choosing from so many various values, and of regarding 
chosen values in so many various degrees, exhausts and finishes us. But God reenacts those values in the universe; and in order to properly meet God's own ongoing satisfaction, the reenactment is not God re-performing our subjective aim, but US performing oUR subjective aim, no longer in act, but in contemplation.

A biblical foundation for the possibility of immortality in Whitehead's metaphysics may not depend as much upon Paul's writings as it may depend upon something worth considering from the Book of Wisdom: "Eor God formed man to be imperishable; the image of his own nature. . . . They seemed, in the view of the foolish, to be dead... yet is their hope full of immortality" (Wisdom 2:23, 3:3,4). In Whitehead's scheme, as objective immortality constitutes the "stubborn fact" of the universe, so subjective immortality, the synthesis of subjective immediacy and objective immortality, constitutes the "stubborn value" of the same universe.

NOTES

'Kenneth F. Thompson, Jr., Whitehead's Philosophy of Religion (The Hague: Mouton and Company, 1971), pp. 7.

${ }^{2}$ Alfred North Whitehead, Process and Reality: An Essay in Cosmology (corrected edition; eds. David Ray Griffin and Donald $W$. Sherbourne; New York: The Free Press, 1978), pp. 56-57 (89). (Bracketed numbers are page references to the 1929 Macmillan edition of Process and Reality.)

$$
\begin{aligned}
& \text { Ibid., p. } 210 \text { [320]. } \\
& \text { [Ibid., p. } 230 \text { [351]. }
\end{aligned}
$$

'This paragraph is in response to comments made by Kenneth Thompson and to a passage from his book (으. cit., n. 19, p. 77).

'Alfred North Whitehead, Modes of Thought (2nd printing, New York: The Macmillian Company, 1957), pp. 29-30.

Ibid., pp. 156-57.

Alfred North Whitehead, Adventures of Ideas (14th printing, New York: The Macmillan Company, 1954), pp. 240-41. 
John B. Cobb, Jr., A Christian Natural Theology (Philadelphia: Westminster Press, 1965), p. $15 \overline{2}$.

${ }^{10}$ Adventures of Ideas, p. 246.

"Lewis S. Ford, The Lure of God (Philadelphia: Fortress Press, 1978), p. 105.

12 Ibid.

${ }^{13}$ Cobb, p. 219.

"Again, this is in response to Kenneth Thompson's remarks.

15 Eord, p. 40.

"Adventures of Ideas, p. 247.

${ }^{17}$ Ibid. (underscore added for emphasis).

I. I.

"Lewis S. Ford and Marjorie Suchocki, "A Whiteheadian Reflection on Subjective Immortality," in Process Studies (Volume 7, Number 1 |Spring, 1977|, 113), p. 5 .

$2{ }^{\circ}$ Eor further reading, see Thompson's work, Part I, Chapter III. "How God Acts," pp. 70-97.

${ }^{2}$ Ford and Suchocki, p. 9.

${ }^{22}$ Process and Reality, pp. 350-51 [532] (underscore added for emphasis).

2 Adventure of Ideas, p. 267.

2*Ford, p. 106.

${ }^{25}$ Cobb, pp. 162-63.

2 "Ford and Suchocki, p. 10.

27 Ibid., p. 11 .

"Ford, p. 106.

29 Ibid.

3o"Is the train of argument in its conclusions substantiated by the identity or vitiated by the diversity?" Modes of Thought, p. 146. 
"John B. Bennett, "The Disembodied Soul," in Process studies (Volume 4, Number 2 [Summer, 1974], $\overline{129-}$ $\overline{1} \overline{3} \overline{5}$, p. $13 \bar{I}$.

12 Alfred North Whitehead, "Immortality," from Alfred North Whitehead: His Reflections on Man and Nature (ed. Ruth Nanda Ashen, lst ed.. New York: Harper and Brothers, 1961), p. 164.

'Ibid., pp. 169-70.

"Again, Thompson's remarks helped me very much.

${ }^{35}$ Eord, p. 74.

"Ibid, pp. 114-15.

${ }^{37}$ Ibid., p. 118.

"Ibid.

"The following remarks are in response to comments by Thompson.

"Both quotes in the paragraph are from "Immortality." p. 159 . 